\title{
NOTE
}

\section{Presence of large virus-like particles in a eutrophic reservoir}

\author{
R. Sommaruga ${ }^{1, *}$, M. Krössbacher ${ }^{1}$, W. Salvenmoser ${ }^{1}$, J. Catalan ${ }^{2}$, R. Psenner ${ }^{1}$ \\ ${ }^{1}$ University of Innsbruck, Institute of Zoology and Limnology, Technikerstr. 25, A-6020 Innsbruck, Austria \\ ${ }^{2}$ University of Barcelona, Department of Ecology, Avgda Diagonal, 645, E-08028 Barcelona, Spain
}

\begin{abstract}
The presence of large virus-like particles (LVLP) without tails was observed in the water of a severely eutrophied freshwater reservoir We used a transmission electron microscope coupled to a semiautomatic image analysing system to study the size distribution of aquatic viruses. The LVLP had maximum head diameters between 195 and $210 \mathrm{~nm}$. Although the affiliation and host of the LVLP are unknown, similarities in size and shape were found with the African swine fever virus. The diffuse organic contamination from piggeries in the catchment area may explain the presence of these LVLP. The observed overlap in size of the LVLP with the smallest bacteria implies serious methodological problems in distinguishing these communities under the epifluorescence microscope. Therefore, although at present we do not know how common LVLP are in other aquatic systems, we discourage the use of epifluorescence microscopy for viral abundance estimations during routine work.
\end{abstract}

KEY WORDS: Virus Plankton Image analysis Epifluorescence microscopy - Freshwater

The development of new methodologies to count viruses has revealed the existence of high abundances (up to $10^{8} \mathrm{ml}^{-1}$ ) in several marine and freshwater systems (Bergh et al. 1989, Bratbak et al. 1990, Hara et al. 1991). This discovery has stimulated research on the role of viruses in aquatic systems. Moreover, viruses are an important concern in water quality management (Melnick 1984) and some authors (Suttle et al. 1990, Proctor \& Fuhrman 1992) have indicated the importance of viruses in the control of bacterial abundance and primary productivity.

Most viruses observed up to now in aquatic systems have been typical phages with head diameters usually between 30 and $150 \mathrm{~nm}$. The majority of viruses, however, are <60 nm (Bergh et al. 1989). They are usually classified into different morphotypes according to Bradley (1967) or Francki et al. (1991). In some detailed

\footnotetext{
•E-mail: ruben.sommaruga@uibk.ec.at
}

studies on morphological diversity of viruses in freshwater and marine environments, only phages have been found (Frank \& Moebus 1987, Demuth et al. 1993). However, particles of icosahedral shape resembling viruses have been described (Bergh et al. 1989, Klut \& Stockner 1990). These particles, usually with diameters between 60 and $120 \mathrm{~nm}$, are assumed either to be phages that have lost their tails or viruses of eukaryotic hosts (Bergh et al. 1989). The denomination of virus-like particles indicates clearly the uncertainty of their affiliation. Bratbak et al. (1992) reported unusually large virus-like particles (LVLP) with head diameters between 340 and $400 \mathrm{~nm}$ (tail present) from coastal waters. They argued that the host of these LVLP was probably a planktonic organism. Polyhedral LVLP $390 \mathrm{~nm}$ in diameter and with tails $1000 \mathrm{~nm}$ long were found associated with the green algae Uronema gigas (Mattox et al. 1972). The largest virus-like particle found up to now (300 to $750 \mathrm{~nm}$ ) was detected inside vacuoles of a marine radiolarian and surrounding waters (Gowing 1993).

Here we report the occurrence of LVLP in an organically polluted freshwater reservoir. These particles, overlapping in size with or even bigger than bacteria, were investigated using a transmission electron microscope (TEM) coupled to a semiautomatic image analyzer. Methodological implications regarding the use of epifluorescence microscopy to distinguish between bacteria and viruses are discussed.

Material and methods. The viruses were found during an intensive study on microbial processes in the epilimnion of Sau Reservoir, Spain $\left(42^{\circ} 51^{\prime} \mathrm{N}, 2^{\circ} 30^{\prime} \mathrm{E}\right)$ Samples were taken in August 1994 from $0.5 \mathrm{~m}$ at a station near the dam (depth: $56 \mathrm{~m}$ ). Water samples were collected with a cone-shaped weight connected to a peristaltic pump. Sau Reservoir was constructed for generation of hydroelectric power, agricultural watering, domestic and industrial water supply and 
recreation. The reservoir was filled in 1963 and its present trophic state is eutrophic. It has a mean surface area of $4.67 \times 10^{6} \mathrm{~m}^{2}$, a mean depth of $25.2 \mathrm{~m}$, a maximum volume of $168.5 \times 10^{6} \mathrm{~m}^{3}$ and a mean water residence time of $0.24 \mathrm{yr}$ (Vidal-Celma \& Tubau 1993). In the catchment area, swine and veal stocks exceeding 600000 individuals are grown intensively. Other characteristics of the system are described elsewhere (Armengol et al. 1989).

Samples for bacteria were fixed with formaldehyde (final conc. $2 \% \mathrm{v} / \mathrm{v}$ ) and stained with the fluorochrome DAPI (Porter \& Feig 1980). Stained samples were concentrated onto membrane filters (Poretics $0.2 \mu \mathrm{m}$ pore size) and observed at $1250 \times$ or $2500 \times$ magnification in a Zeiss epifluorescence microscope with a BP 365, FT 395, and LP 397 filter set. Image analysis of DAPIstained particles was made at $2500 \times$ magnification as described in Psenner (1993).

From the bacterial samples, $100 \mathrm{ml}$ was concentrated to approximately $100 \mu \mathrm{l}$ using a filter of $0.1 \mu \mathrm{m}$ pore size (Anotec, England). The viruses were adsorbed by dipping a carbon-coated copper grid into the concentrated sample. The grids were rendered hydrophilic by high-voltage glow discharge. Afterwards the grid was covered with 1 drop of $0.2 \mu \mathrm{m}$ filtered uranyl acetate $(2 \% \mathrm{w} / \mathrm{v})$ for negative staining for a duration of $30 \mathrm{~s}$. Excess stain was removed with a filter paper. The sam-

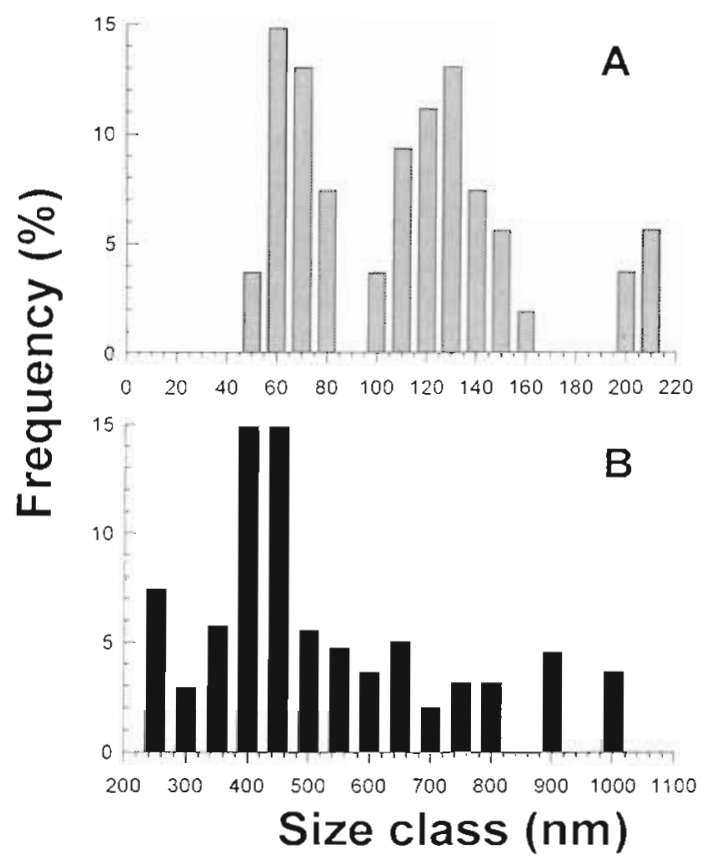

Fig 1. Size-frequency plot of maximum diameter of individual heads of (A) phages and large virus-like particles $(N=210)$ measured by image analysis in the transmission electron microscope and $(B)$ DAPI-stained particles $(\mathbb{N}=624)$ measured in the epifluorescence microscope ples were examined with a Zeiss 902 TEM at $80 \mathrm{kV}$ accelerating voltage and a magnification between $30000 \times$ and $85000 \times$. With this procedure we obtained good adsorption of viruses even smaller than the pore size of the filter and also bacteria and cyanobacteria on the carbon-coated grid. Different types of viruses were recognized on the basis of size, morphology of the head and, if present, characteristics of the tail.

In addition to the photographs from the TEM we used a semiautomatic image analysis system connected to the TEM to collect information on the size distribution of the viruses. This allowed us to enhance morphological characteristics and to determine the size of the viruses with high accuracy. The system uses a high sensitivity SIT camera (Dage Camera, Zeiss, Germany). The image analysis software (LUCIA, Prague) was used in combination with a real-time image processor (MATROX MVP-AT, Canada). Digitized images taken at 30000 to $50000 \times$ magnification were resolved with $512 \times 512$ pixels using 8 bits of memory. The system was calibrated with a calibration grid for electron microscopy (Plano, Marburg, Germany) and determinations were also checked with the TEM micrographs.

Results and discussion. Three groups of viruses, clearly distinguishable by their head diameters, were found in Sau Reservoir (Fig. 1A). The first 2 groups, with head diameters of 45 to $80 \mathrm{~nm}$ and 100 to $160 \mathrm{~nm}$ (Fig. 2C, D), were represented by phages. As the morphology of bacteriophages and cyanophages is similar we were not able to distinguish between them. However, the relatively large head diameter of some of them (100 to $160 \mathrm{~nm}$ ) suggests that they may be cyanophages. Moreover, during sampling a bloom of cyanobacteria (25 to $50 \mathrm{mg} \mathrm{chl} \mathrm{a} \mathrm{m}^{-3}$ ) dominated by Synechocystis sp. was present. We did not observe neck filaments characteristic of viruses infecting freshwater filamentous cyanobacteria (Padan \& Shilo 1973) but not unicellular forms like Synechocystis. However, considering the head diameter of these phages we did not find any similarity to those previously described by Safferman et al. (1983).

The third group corresponds to LVLP (Fig. 2A, B) with diameters between 195 and $210 \mathrm{~nm}$. The LVLP were polyhedral with 6-sided capsids (Fig. 2A, B). Although we did not section the LVLP they resembled those observed by Gowing (1993). However, the LVLP found by Gowing inside a marine radiolarian were even larger (diameter 300 to $750 \mathrm{~nm}$ ). Also the micrographs of negatively stained virus-like particles shown in Bergh et al. (1989, their photos $1 \mathrm{e}-\mathrm{g}$ ) are consistent with ours, although in this case their virus-like particles were smaller. The icosahedron is a common shape for animal, algal and bacterial viruses (Palmer \& Martin 1988, Van Etten et al. 1991). For instance, the LVLP in Fig. 2B have a very similar size and morphology to 

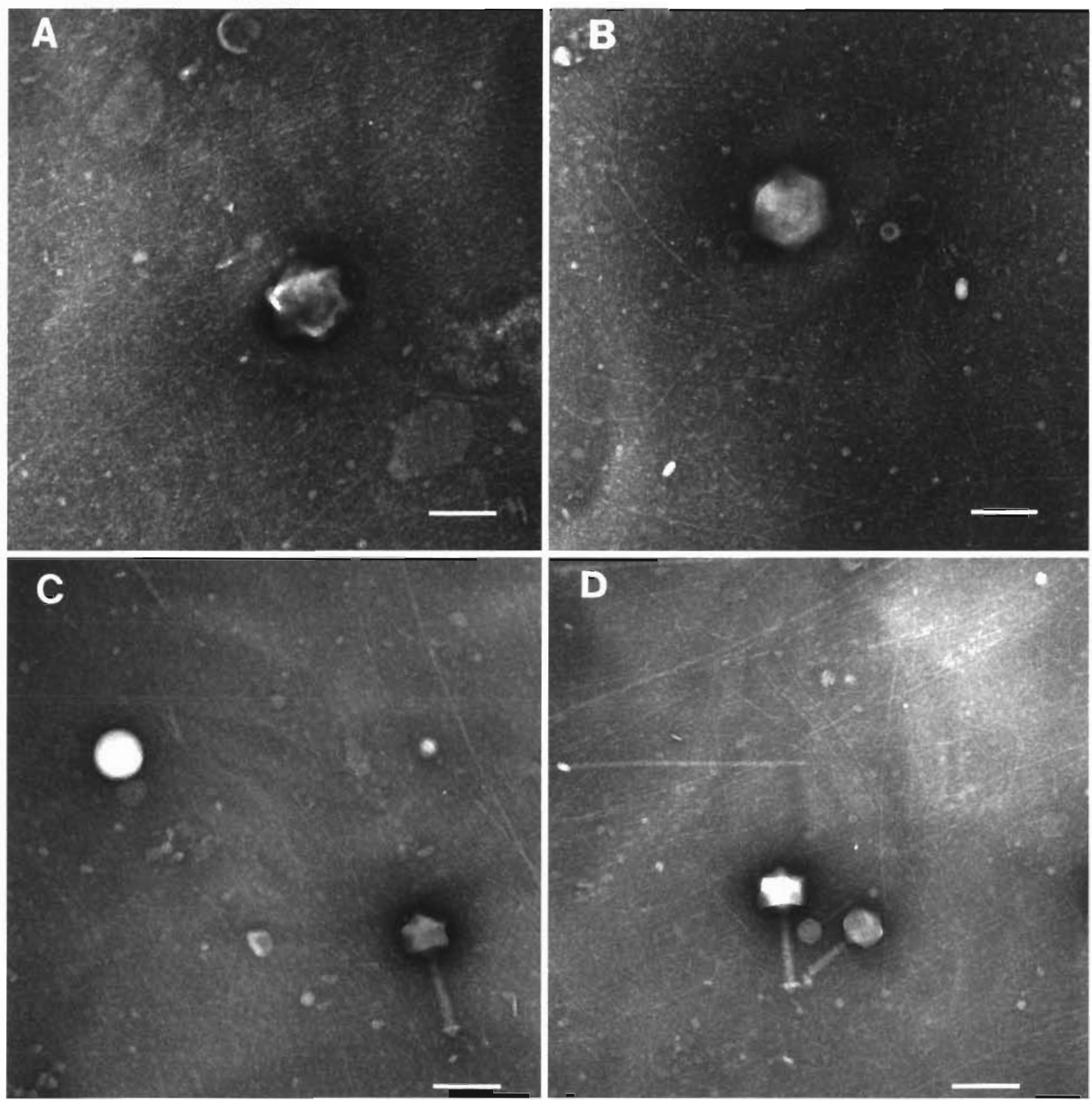

Fig. 2. Transmission electron micrographs of phages and large virus-like particles (LVLP) found in the epilimnion of Sau Reservoir, Spain. (A) LVLP with polyhedral shape; (B) 6-sided icosahedral LVLP; (C) coccoid bacteria and a phage with head of similar diameter; (D) different sizes of phages. Scale bars $=175 \mathrm{~nm}$

the African swine fever virus with a diameter of about $200 \mathrm{~nm}$ (Viñuela 1985). This deoxyvirus was found originally in Africa but has also been found in America and Europe, including Spain (Viñuela 1985 and references therein). Although we do not know with accuracy the origin of the LVLP, the diffuse organic contamination from piggeries in the catchment area of Sau Reservoir is a plausible explanation. The virus has been also isolated in Spain from ticks (Acari) (Sánchez Botija 1963).
In Fig. 1B the result of an image analysis of DAPIstained particles is shown. The smallest particles measured were $210 \mathrm{~nm}$ in diameter. The finding of LVLP overlapping in size with bacteria (see Fig. 2C) has very important methodological implications. Epifluorescence microscopy incorporating the use of fluorochromes, e.g. DAPI, to make direct counts of bacteria and viruses is actually a common technique in water research (Hara et al. 1991, Proctor \& Fuhrman 1992, Suttle 1992). Although viruses are beyond the resolu- 
tion limit of the light microscope, viral particles with DNA contents of as few as 4 to $6 \mathrm{~kb}$ can be observed under the epifluorescence microscope (Proctor \& Fuhrman 1992). These authors suggested that the highly condensed state of viral DNA is responsible for the particularly bright fluorescence. In samples like those from Sau Reservoir, separation between small coccoid bacteria and LVLP is not possible under the epifluorescence microscope $(2500 \times)$ or using microscopic photographs as described in Hara et al. (1991). A routine counting of bacteria without previous knowledge of virus particle size distribution will lead to an overestimation. This fact may also disturb bacterial cell volume determinations producing an underestimation of the mean cell volume. Alternative methods of estimating bacterial abundance and cell volume have recently been discussed (Heldal et al. 1994). Conversely, it would be impossible to count viruses in Sau Reservoir using this method. As studies of aquatic viruses in different systems are still scarce and samples have frequently been prefiltered (Paul et al. 1991) we do not know at present how common the presence of LVLP in aquatic systems is. Although we did not use a quantitative recovery method for viruses and we thus ignored their real abundance, we observed clouds of very tiny fluorescent DAPI-stained particles. Therefore we discourage the use of epifluorescence microscopy for viral abundance estimations in natural samples during routine work.

Acknowledgements. We thank the staff of the Department of Ecology, Barcelona, for cooperative work at Sau Reservoir and K. Monz for helping with the glow discharge. We are grateful to J. Campione (National Laboratory for Disease Control, Canada) for contributing data from the literature on the African swine fever virus and cyanophages. This work was supported by the Ministry of Science of Austria and Spain through the cooperative scientific program 'Acciones Integradas' (contract no. 94/30).

\section{LITERATURE CITED}

Armengol J, Crespo M, Morgui JA, Vidal A (1989) Phosphorus budgets and forms of phosphorus in the Sau Reservoir sediment: an interpretation of the limnological record. Hydrobiologia 143:331-336

Bergh $\varnothing$, Børsheim Y, Bratbak G, Heldal M (1989) High abundance of viruses found in aquatic environments. Nature $340: 467-468$

Bradley DE (1967) Ultrastructure of bacteriophages and bacteriocins. Bacteriol Rev 31:230-314

Bratbak $G$, Haslund $O H$, Heldal $M$, Næess A, Røeggen $T$ (1992) Giant marine viruses? Mar Ecol Prog Ser 85 201-202

Bratbak G, Heldal M, Norland S, Thingstad TF (1990) Viruses as partners in spring bloom microbial trophodynamics Appl environ Microbiol 56:1400-1405

Demuth J, Neve H, Witzel KP (1993) Direct electron microscopy study on the morphological diversity of bacteriophage populations in Lake Plußsee. Appl environ Microbiol 59:3378-3384
Francki RIB, Fauquet CM, Knudson DL, Brown F (1991) Classification and nomenclature of viruses. Fifth report of the International Committee on Taxonomy of Viruses. Arch Virol Suppl 2:1-450

Frank H, Moebus K (1987) An electron microscopic study of bacteriophages from marine waters. Helgoländer Meeresunters $41: 385-414$

Gowing M (1993) Large virus-like particles from vacuoles of phaedoraian radiolarians and from marine samples. Mar Ecol Prog Ser 101:33-43

Hara S, Terauchi K, Koike I (1991) Abundance of viruses in marine waters: assessment by epifluorescence and transmission electron microscopy. Appl environ Microbiol 57: $2731-2734$

Heldal M, Norland S, Bratbak G, Riemann B (1994) Determination of bacterial cell number and cell volume by means of flow cytometry, transmission electron microscopy, and epifluorescence microscopy. J microbiol Meth 20:255-263

Klut ME, Stockner JB (1990) Virus-like particles in an ultraoligotrophic lake on Vancouver Island, British Columbia. Can J Fish Aquat Sci 47:725-730

Mattox KR, Stewart KD, Floyd GL (1972) Probable virus infections in four genera of green algae. Can $J$ Microbiol $18: 1620-1621$

Melnick JL (1984) Etiologic agents and their potential for causing waterborne virus diseases. In: Melnick JL (ed) Enteric viruses in water. Monographs in virology, Vol 15. Karger, Basel, p 1-16

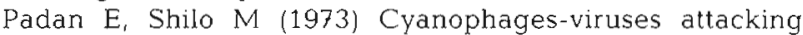
blue-green algae. Bacteriol Rev 37:343-370

Palmer EL, Martin ML (1988) Electron microscopy in viral diagnosis. CRC Press, Boca Raton

Paul J, Jiang SC, Rose JB (1991) Concentration of viruses and dissolved DNA from aquatic environments by vortex flow filtration. Appl environ Microbiol 57:2197-2204

Porter K, Feig YS (1980) The use of DAPI for identifying and counting aquatic microflora. Limnol Oceanogr 25:943-948

Proctor LM, Fuhrman JA (1992) Mortality of marine bacteria in response to enrichments of the virus size fraction from seawater. Mar Ecol Prog Ser 87:283-293

Psenner R (1993) Determination of size and morphology of aquatic bacteria by automated image analysis. In: Kemp $P_{\text {, }}$ Sherr B, Sherr E, Cole J (eds) Handbook of methods in aquatic microbial ecology. Lewis Publishers, Boca Raton, p $339-346$

Safferman RS, Cannon RE, Desjardins PR, Gromov BV, Haselkorn R, Sherman LA, Shilo M (1983) Classification and nomenclature of viruses of cyanobacteria. Intervirology 19:61-66

Sánchez Botija C (1963) Reservorios del virus de la peste porcina africana: investigación del virus de la P.P.A. en los artrópodos mediante la prueba de la hemadsorción Bull Off int Epiz 60:895-899

Suttle CA. (1992) Inhibition of photosynthesis in phytoplankton by the submicron size fraction concentrated from seawater. Mar Ecol Prog Ser 87:105-112

Suttle CA, Chan AM, Cottrell MT (1990) Infection of phytoplankton by viruses and reduction of primary productivity: Nature 347:467-469

Van Etten JL, Lane L, Meints MH (1991) Viruses and viruslike particles of eukaryotic algae. Microbiol Rev 55:586-620

Vidal-Celma A, Tubau JO (1993) The eutrophication process in Sau Reservoir (NE Spann): a long term study. Verh int Verein Limnol 25:1247-1256

Viñuela $E$ (1985) African swine fever virus. In: Willıs DB (ed) Current topics in microbiology and immunology, Vol 116 Springer-Verlag, New York, p 151-170 